\title{
石炭灰造粒物の海底被覆による 海域環境の改善効果 \\ A STUDY OF MARINE ENVIRONMENTAL IMPROVEMENT THROUGH COVERING ON SEABED WITH FLY ASH BEANS
}

\author{
井上省吾 $1 \cdot$ 西野博史 $^{1} \cdot$ 木村道夫 $1 \cdot$ 日比野忠史 $2 \cdot$ 首藤啓3 \\ Shogo INOUE, Hiroshi NISHINO, Michio KIMURA, \\ Tadashi HIBINO and Akira SUTO
}

\author{
1国土交通省中国地方整備局広島港湾空港技術調査事務所（７ 730-0029 広島市中区三川町2-10) \\ 2正会員 工博 広島大学大学院工学研究科 准教授 ( 7739 - 8527 東広島市鏡山1-4 1) \\ 3正会員 工修（財）港湾空間高度化環境研究センター（广 105-0001 東京都港区虎ノ門三丁目1-10)
}

\begin{abstract}
A prototype model experiment was conducted to verify the effectiveness of covering the seabed with fly ash beans to improve the environment in marine areas contaminated by organic sludge buildup. The site of the experiment was Kaita Bay, located in the innermost region of the Hiroshima Bay in Japan. Three different thicknesses of the covering layer were tried in three separate areas. Over approximately six months, the site was monitored, and the degree of improvement is assessed based on monitoring data. Data was gathered on water quality, sediment, interstitial space of beans, and benthos.

It was found that fly ash beans contributes positively to the improvement of the marine environment, as it is effective at suppressing suspended mud. This material is a likely contributor to sludge breakdown, and alters the environment in a manner favorable to habitation of benthos by decreasing hydrogen sulfide concentration and otherwise improving water quality.
\end{abstract}

Key Words : Fly ash beans, sediment, water quality,prototype model, improvement technique

\section{1.はじめに}

東京湾, 伊勢湾 , 瀬戶内海などの閉鎖性海域では, 富栄養化と光れに伴う赤潮, 貧酸素水塊などの問題 に対応するため，陸域から流入する COD, リン，窒 素の負荷削減対策が行われており，赤潮発生に伴う 漁業被害の減少など一定の効果か現れている。しか し，一部の海域では依然として貧酸素水塊の発生な どが見られており，第 6 次水質総量規制においては， 対策の方向性として，陸域負荷の削減だけではなく， 底泥からの栄養塩類の溶出を抑制するための底泥の 除去や覆砂などの底質改善対策の必要性が述べられ ている1).

広島湾の奥部に位置する海田湾は, ヘドロの堆積 が著しく進行し，広島湾の中でも最も污濁した場所 であり，夏季の貧酸素化等の問題が生じている海域 である. 平成 19 年 3 月に策定された広島湾再生計 画 $^{2)}$ では, 海田湾がアピールエリアの一つとして 選定され、親水などの利用に適した水環境を再生す る取り組みが求められている。

一般的に海域環境の改善方策として，陸域からの
負荷低減，干潟造成や藻場造成といった自然再生， 底泥の浚渫, 覆砂などの各種取り組みが実施されて いる . 海田湾の現況であるへドロの堆積がもたらす 影響を効果的に改善する手法として，石炭灰造粒物 の海底被覆の方法が提案されている31，4)，5)。

石炭灰造粒物は, 比重が軽くへドロへの沈み込み を軽減でき, 造粒物自体の吸着効果, 浮泥の舞い上 がり抑制効果などが期待されている．また，有機物 の分解についても造粒物間の空隙を確保でき適正な 環境を形成することで促進ができると考えられる .

本研究は, このような石炭灰造粒物のもつ特性を 活用し, 海域環境を改善する方法の効果について, 現地実証試験による評価を行った . 実証試験の施工 後約半年が経過した時点で,ここまでの調査結果に ついて整理し、開始前と比較・分析を行った。

\section{2 . 現地実証試験の概要}

\section{（1）実証試験の実施場所}

石炭灰造粒物の海底被覆による海域環境改善効果 を検証するために，平成 21 年 5 月より約 2 ヶ月の 
期間で試験区の施工を行った．場所は，图-1に示 す海田湾の最奥部で坂なぎさ公園前の堀込み状の海 域で, 幅 190m, 長さ $315 \mathrm{~m}$ の範囲で 6ha を 3 分割し て, 異なった条件にて試験区を設けている .

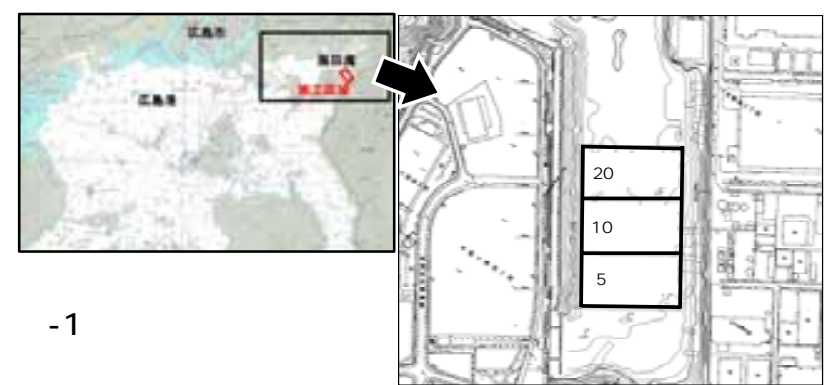

\section{（2）試験区の構造}

海域改善効果に対して，石炭灰造粒物の被覆厚さ が大きな要素と考えられるため，3 区画は厚さを $5 \mathrm{~cm}, 10 \mathrm{~cm}$, および $20 \mathrm{~cm}$ として施工した . 图-2 は， 試験区の縦断方向の断面図を模式的に示している. これら試験区の違いによって，特に海域環境改善効 果の持続期間が比較できるものと考えられる .

南揑

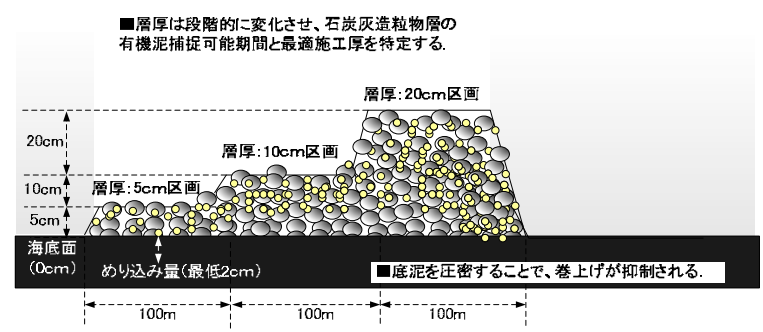

図- 2 実証試験区画の設計構想

3．モニタリング調査結果

\section{(1) 調査項目}

実証実験の海域環境改善効果を把握するために、 主とした着眼点は次の3つである。

(1)水・底質の改善効果 : 水質及び底質の DO, ORPな どの項目の変化

(2)底生生物への効果 : 生物量の変化, 生息場の状態 (3)被覆層の有機物捕捉 - 分解、浮泥の移動抑制効 果 : 被覆層内での物理・化学的な性状変化など

これらの改善効果を把握するために，被覆層内， 水中部，底質，生物調査などの調査を実施した。

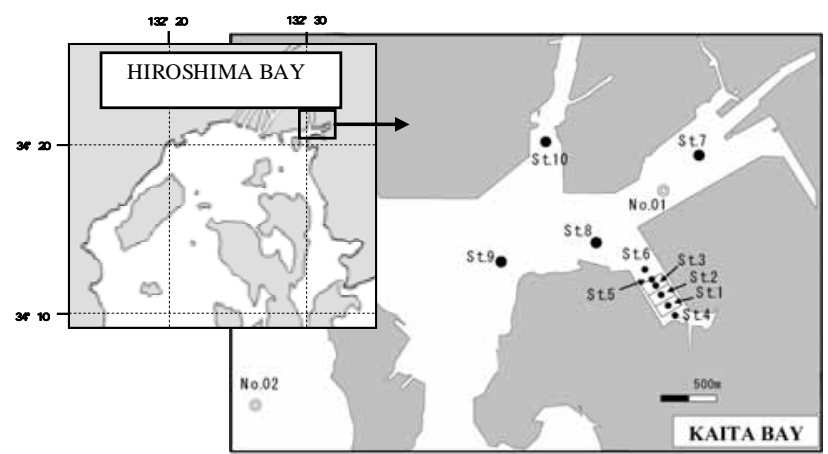

図-3 現地調査地点
（2）調査位置 $\cdot$ 時期

图-3に各調査の測点を示す.また，表- 1 に施工 後, 主に夏季と冬季に行った調査項目と測点の関係 を示す.なお,試験区 St 1〜3 については各試験区 を 3 分割した中央点に測点を設け, 各試験区の両側 にも測点を設定して，枝番で表記している.

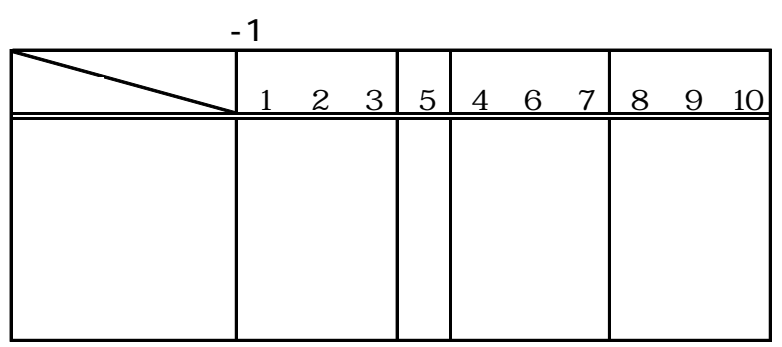

(3) 調査結果

実証実験を進めるにあたって，試験区の施工前か ら各種調査データを蓄積しており, 試験開始の約半 年が経過したデータまでを整理した . 試験区周辺の 状況，および試験区の結果の順に以下に示す．

a) 海田湾の海域環境特性

試験区周辺の状況を既存資料によって取りまとめ た. 平成 22 年度の気象については, 暑い夏を裏付 けるように広島でも平均気温で前 2 年と比べ 8 月と 9 月で $2^{\circ} \mathrm{C}$ 程高くなった．降水量をみると，6月と 7 月は集中的な降水の影響で平年より多く，8月〜10 月は平年を大きく下回った状態であった ${ }^{6)}$.

海域の環境については, 広島湾の水質調査結果 7) から測点 No.01の 7 月〜10 月の結果を過年度の 結果を比較すると，8月は 7 月までの多雨の影響か ら 22 年度が特に表層近くで低塩分, 高 DO, クロロ フィルaが高いことがわかる.9 月になると, 全層 で濁度が高く，DO は前年並に $4 \mathrm{~m}$ 以深で貧酸素状態 ( 2ng/L) となっている . なお, 海田湾口部の測点 No. 02 をみると，DOが 7 月〜9 月で №.01より 2〜 4ng/L 高いことから海田湾につながる広島湾からの 影響は貧酸素の悪化の観点からは光れほど大きく関 与していないと考えられる .

b) モニタリング調査結果

表- 1 に示した調査項目から主な結果を以下に列 記する 。

(1)水質

图-4 は, 試験区と対照区 (图-3，表-1 参照) に おける施工前後の水質鉛直分布を比較したものであ る. 試験区と対照区では背後地からの流入条件が 異なることから，出水による違いはあるものの概ね 同じような挙動で変化している. 施工後についても 大きな違いは認められず, 一つの入り江単位では水 質の変化まで及ぼしていないと考えられる.

图-5は，試験区に焦点をあて時期の異なる DO と 濁度の断面分布を比較したものである．また，連続 観測結果より, 底質 DO と濁度の平均值を比較して 表- 2 に示す. . 施工後の 8 月では, 濁度の変化はな いものの DO か対照区と比べ高くなっており，平均 值で小潮期には $0.3 n g / L$ 程度高い傾向である . 冬季 
では濁度が低下しており試験区での効果が現れつつ あることが考えられる

海域の水質は潮汐などの影響によって時々刻々と 変化するため, 水質結果の普遍性と短期的な現象に ついて把握するために, 夏季には水質の連続も実施 した . 图- 6 は試験区と両隣りの対照区とを比較し た水温,塩分, 流速, 濁度, および DOの連続観測結

表- 2 底質 DOおよび濁度の連続観測の平均値

\begin{tabular}{|c|c|c|c|c|c|c|c|c|}
\hline & \multirow{2}{*}{ Time } & \multirow{2}{*}{$\mathrm{n}$} & \multicolumn{2}{|c|}{ ST.2-1 } & \multicolumn{2}{|c|}{ ST.4 } & \multicolumn{2}{|c|}{ ST.6 } \\
\hline & & & Ave. & S.D. & Ave. & S.D. & Ave. & S.D. \\
\hline 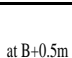 & $S^{*}$ & 625 & 1.1 & 0.6 & 0.6 & 0.6 & 0.8 & 0.5 \\
\hline$(\mathrm{mg} / \mathrm{L})$ & $\mathrm{N}^{*}$ & 1535 & 1.5 & 0.5 & 1.8 & 0.8 & 1.4 & 0.4 \\
\hline $\begin{array}{l}\text { Turbidity } \\
\text { at } \mathrm{B}+0.2 \mathrm{~m}\end{array}$ & $s^{*}$ & 625 & 7.4 & 3.6 & 6.6 & 3.2 & 6.2 & 2.5 \\
\hline (ppm) & $\mathrm{N}^{*}$ & 1535 & 3.3 & 0.8 & 6.6 & 5.8 & 4.6 & 2.1 \\
\hline
\end{tabular}
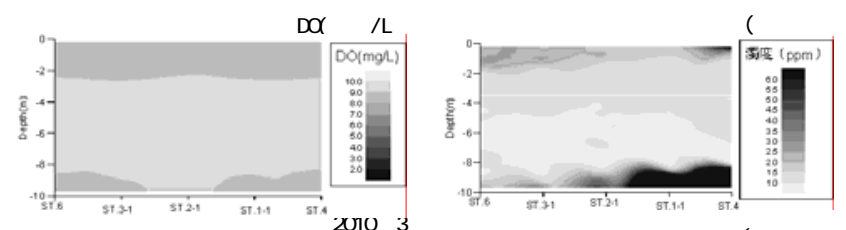

$\mathrm{DQ}(\mathrm{mg} / \mathrm{L})$
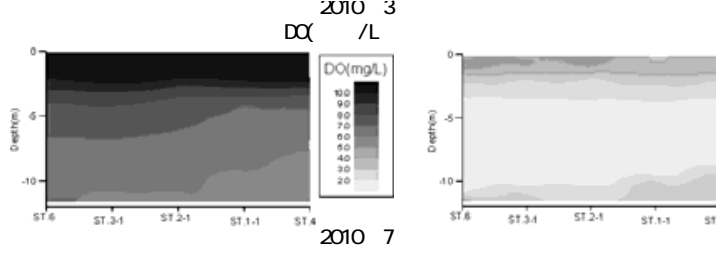

蜀度 $(\mathrm{p} \mathrm{p} \mathrm{m} \mathrm{)}$

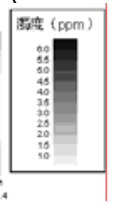

DO $\mathrm{m} \mathrm{g} / \mathrm{L})$

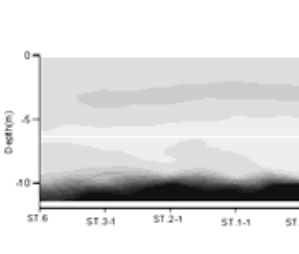

度 $(\mathrm{p} \mathrm{p} \mathrm{m)}$
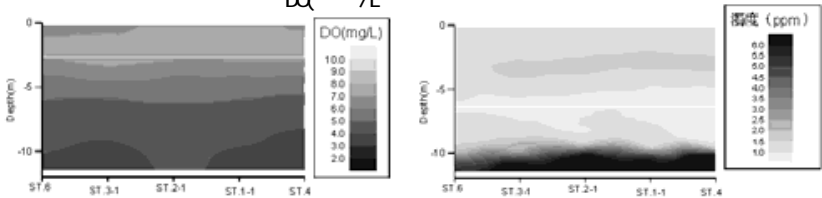

2010年8

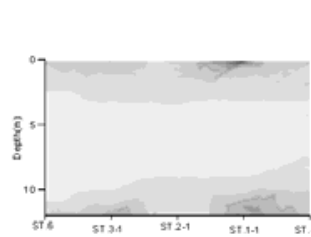

濁度 $(\mathrm{p} \mathrm{p} \mathrm{m})$
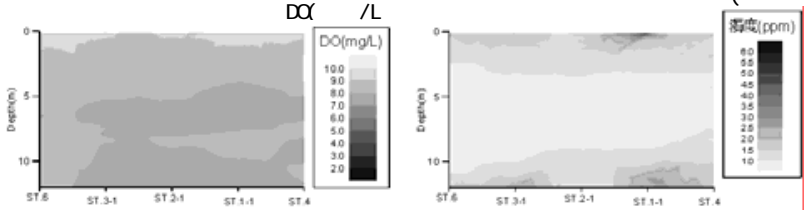

2010年12月 (施工後)

図- 5 施工前後の水質断面分布
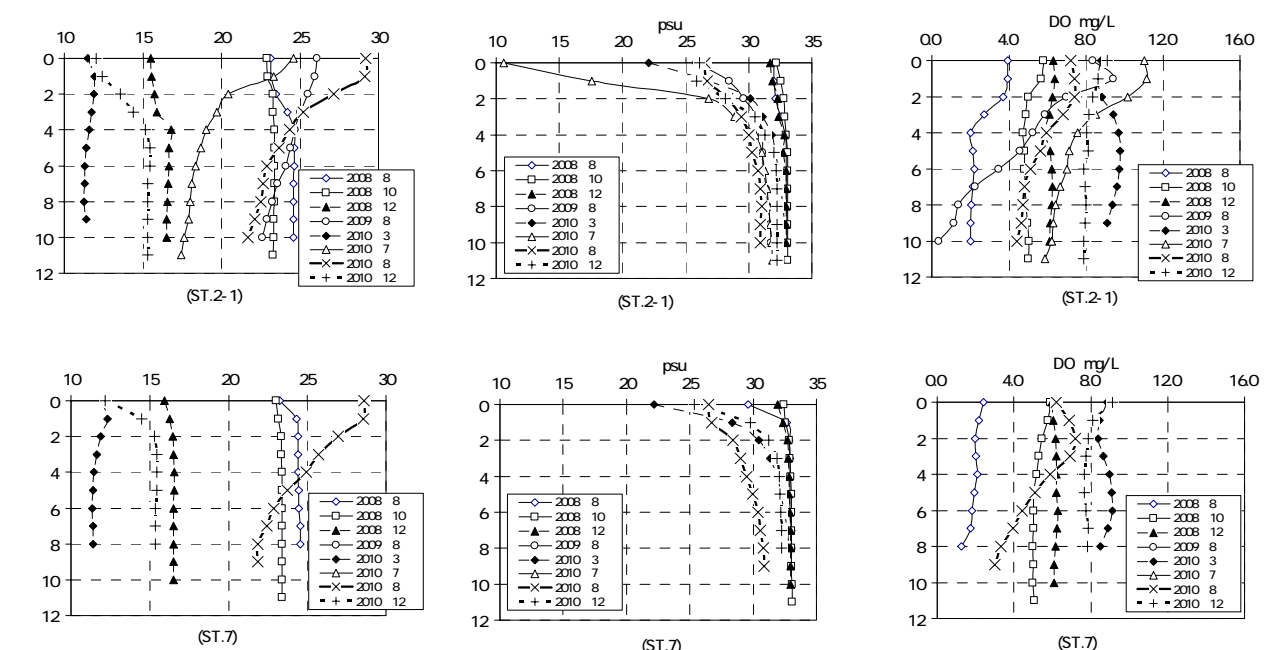

図-4 施工前後の水質鉛直分布
果である.9月 8 日から 9 日に出水により大きな変 化を伴い前後の時期では濁度の変化が異なっている． 8 日以前は小潮・中潮で流速が弱く浮泥が底層近く で広く漂う状況と解釈できる．一方，9月 9 日以降 では大潮期で流速が強くなり全般的に濁りは軽減さ れる.この時期では試験区での濁度は対照区と比べ 低減することが認められた．DOの変化では，8日以 前は試験区で高くなっているが，9 日以降は広島湾 からの影響を受け全体的に上昇している．
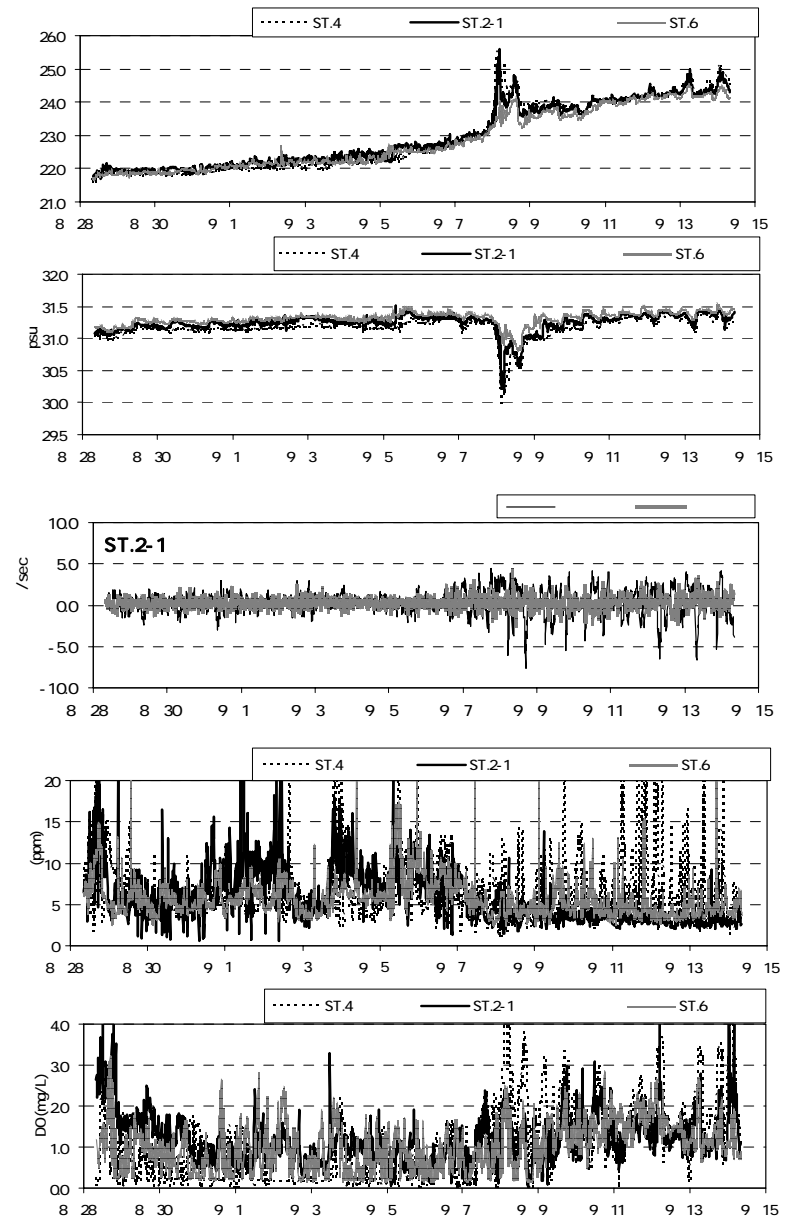

図- 6 海底面上 $0.2 \mathrm{~m}$ の水温、塩分、流速、濁度 および $0.5 \mathrm{~m}$ の DOの時系列変化 


\section{(2)底質}

被覆層内および底質の調査結果から含水比, $\mathrm{pH}$, ORP , T- S , I L , PON を图- 7 に示す. 含水比をみる と浮泥の性状が明らかに異なることが判る．対照区 で夏季 550\%，冬季 300\%に対し試験区は夏季 50〜 100\% , 冬季 25〜150\%で $5 \mathrm{~cm}$ 区が高くなりつつあ る. pH は施工直後の試験区では対照区より 1〜1.5 高かったが 12 月には 8 程度と 0.5 高い值に低減し ている。

ORP と T- S は $5 \mathrm{~cm}$ 区画では対照区と同程度の数値 となっているが, $10 \mathrm{~cm}$ おび $20 \mathrm{~cm}$ 区画では改善し ている.IL と PON も同じ傾向で $5 \mathrm{~cm}$ 区画は対照区 と同程度であるが, $10 \mathrm{~cm}$ おび $20 \mathrm{~cm}$ 区画では低減 している.夏季から冬季にかけて $5 \mathrm{~cm}$ 区では対照区 の数值に近づく傾向となっている.沈降粒子は IL， PON 共に高く，水中から海底に達して分解等で低く なるが, 試験区ではさらに低減することが判る．

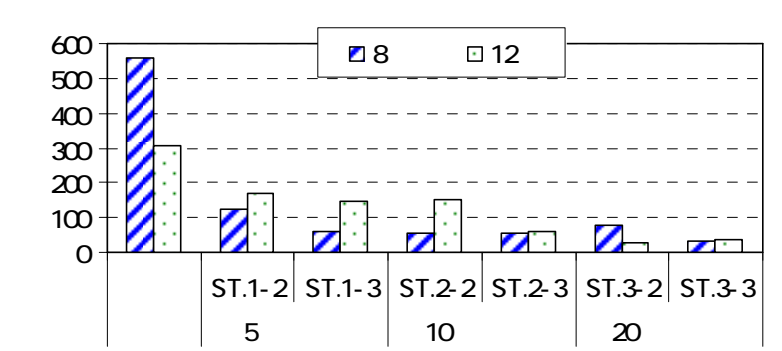

(a) 含水比

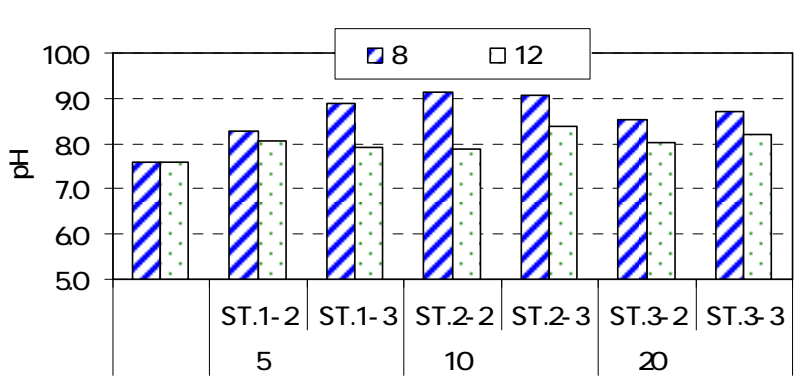

(b) $\mathrm{pH}$

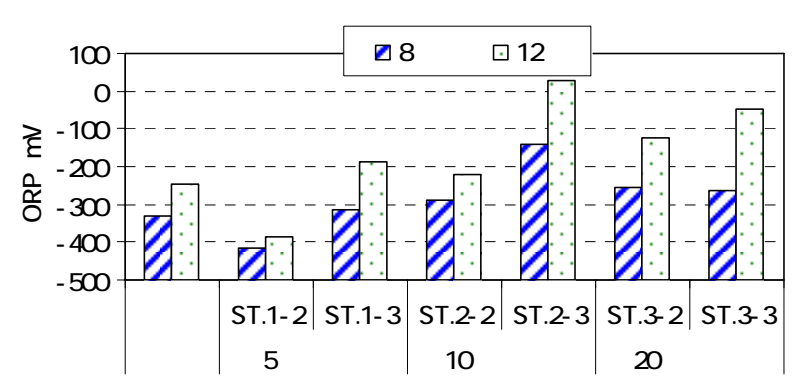

(c) ORP

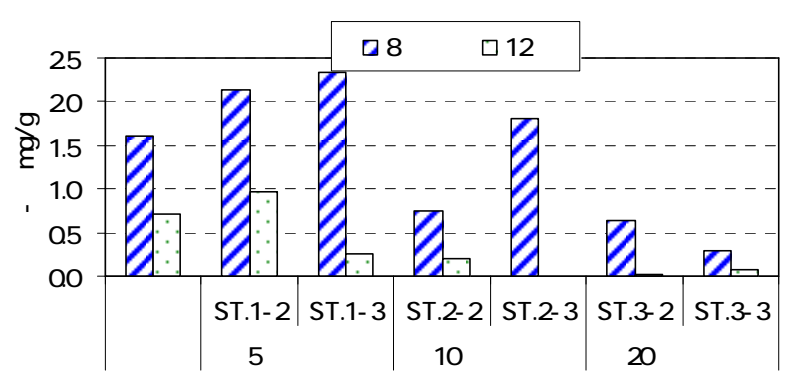

(d) T- S

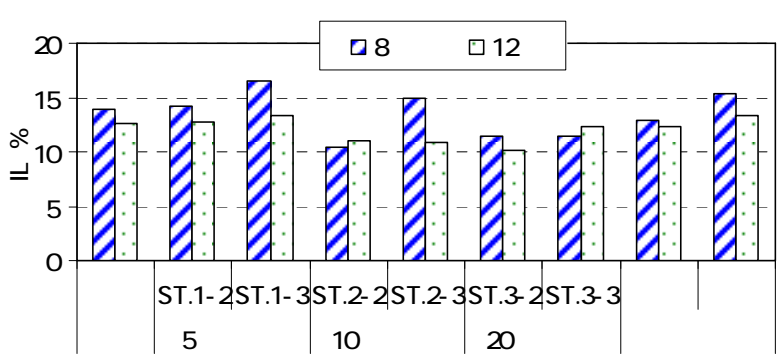

(e) I L

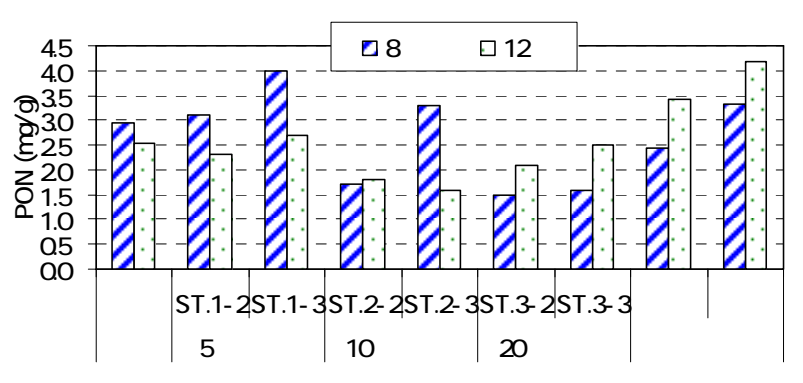

(f) PON

図- 7 底質調查結果

(3)間隙水の水質

底質間隙水および被覆層内の水質を图-8に示す． 試験区での栄養塩濃度は低く，硫化水素は検出しな いことが判る . 試験区では底質からの栄養塩溶出を 制御しており, また, 石炭灰造粒物の硫化水素の吸 着効果 ${ }^{8)}$ 等により，硫化水素濃度が低減し，生物 の生息環境が改善されていることが判る .

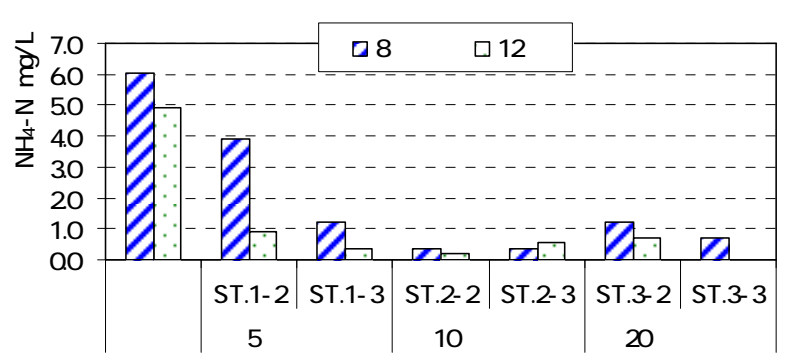

(a) NH4 N

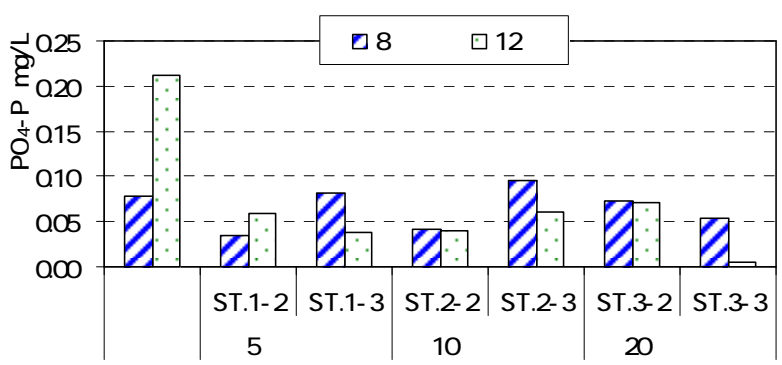

(b) $\mathrm{PO} 4 \mathrm{P}$

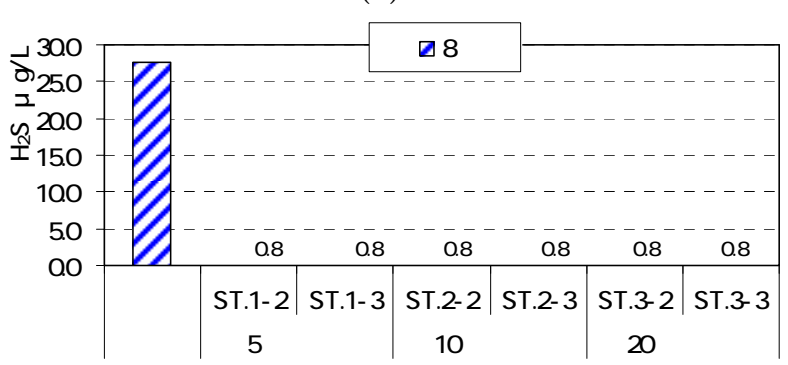

(c) H2S

図-8 間隙水の水質 


\section{(4)底生生物}

图-9 に試験区中央部における施工前後の底生生 物の現存量の比較を示す. 種類数, 個体数, 湿重量 共に施工前と比へ増加していることが認められる . 出現種では, 夏季には主にゴカイの仲間である環形 動物が多かったのに対し，冬季にはヨコエビ等の節 足動物が多く見られた。
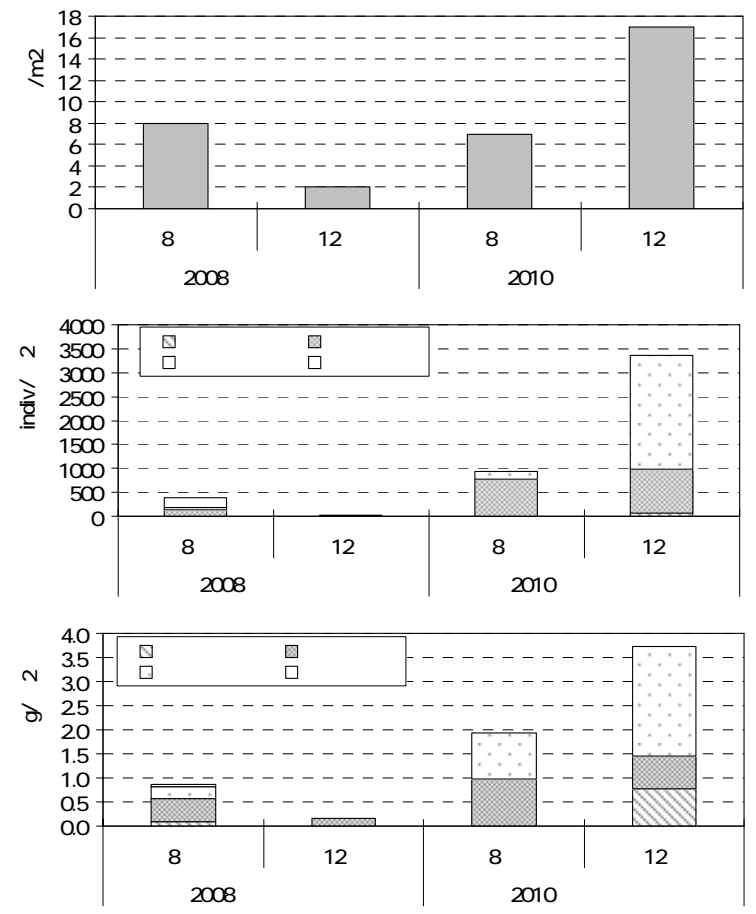

図- 9 施工前後の底生生物現存量

\section{4 . 被覆層の底質改善効果}

石炭灰造粒物の海底被覆は，現底質の覆砂効果と 水中部の浮泥取り込み効果を狙ったものである.し たがって，被覆層が海底面からある程度の高さを保 ち, 空隙率も確保している必要がある. 被覆層の物 理的な状態と底質の改善状態を比較検討し, 改善効 果が発揮できる耐用年数を評価するために，粒子の 挙動と特質について整理した。

\section{（1）被覆層間隙体積に占める浮泥体積の割合}

图- 10 に被覆層間隙体積に占める浮泥体積の割合 の変化を示す . 施工直後から 3 区画の違いをみると， $5 \mathrm{~cm}$ 区画か時間と共に増加し 12 月には $40 \%$ 程度と なっている．一方，他の2つの区画では，むしろ低 下傾向を示している. 施工後半年間の期間内の比較 では、明らかに $5 \mathrm{~cm}$ 区画が異なった推移で間隙率が 減少している。

ぞの要因としては, 浮泥が層内で増えると固液混 相流状態が強まり鉛直密度勾配が大きくなり, 新た に海水が侵入した際の海水交換の低下に働くことが 考えられる .

\section{（2）SSの動態}

浮泥の動態を模式的に示すと图- 11 のように表す ことができる . 水中部の SS は徐々にではあるが沈 降し, 被覆層の表面に堆積するものと, 層内に取り 込まれるものに分かれる.層内に取り込まれた SS は間隙層に堆積し, さらに原地盤の底質に移動する もの, 水平的に消失するもの, 分解によって形状を 変えるものなど, 幾つかの要因で堆積物は減じるこ とになると考えられる . なお，夏季と冬季と 2 分し ているが, 沈降は積算の数值であり表層および間隙 部の堆積は瞬間値であるため, 正確な出入りを表し ているものではない .

沈降，表層への堆積，間隙部への堆積，および収 支として算出される消失分について，7，8 月と 9 月から 12 月の 2 期間での概略のフラックスとして 示している。

表層への堆積は，いずれの区画でも 12 月には 0 に近づき定常状態になりつつ, 被覆層間隙への堆積 は $5 \mathrm{~cm}$ 区画では増加，10cm 区画ではほぼ $0,20 \mathrm{~cm}$ 区画ではマイナスに変わっている.5cm 区画では堆 積が進み本来の機能が低下し, 10cmと 20cm区画で は被覆層の初期の形状を保ち改善機能が発現されて いることが予想される .

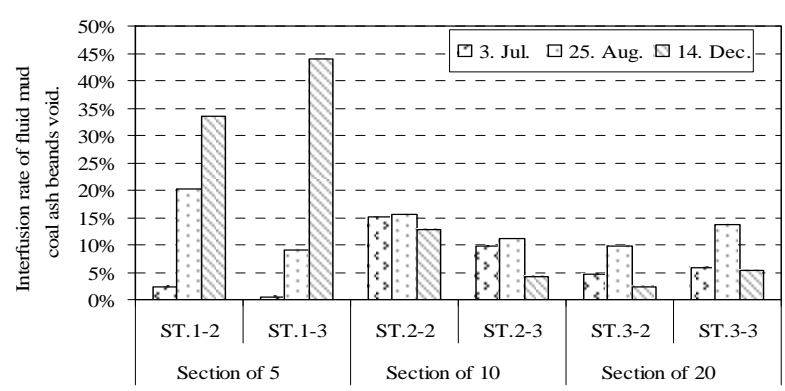

图-10 被覆層間隙体積に占める浮泥体積の割合

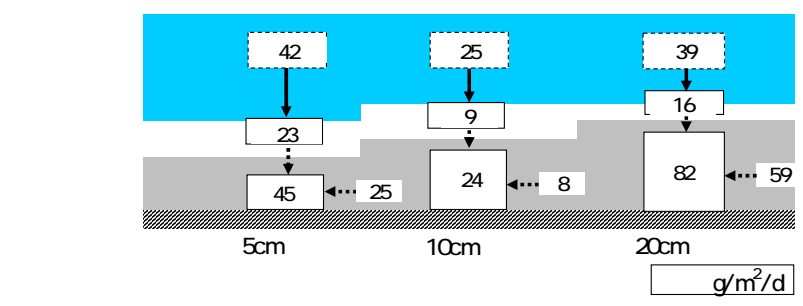

(a) 夏季 (7〜8月)

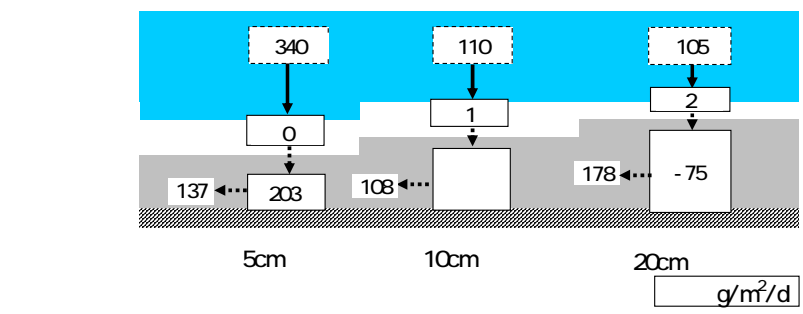

(b) 冬季 (9〜12月)

図-11 被覆層間におけるSSの動態 
（3）被覆層内の浮泥の質的変化

3.で示したモニタリング調査結果から，5cm区 画の底質が他の 2つの区画と違いが生じ始めている ことが想定される．IL，PON 等の值が対象区に近づ く方向で変化し始めていること, 上記に示した被覆 層間隙部への堆積増加が進んでいることから，改善 効果は 12 月時点で発揮されなくなったものと判断 できる．また，収支として算出した消失分の要因や 内訳については今後の課題ではあるが, 有機物の分 解による減容化は I L や PON の低下をみると要因の 一つと考えられる .

\section{（4）舞い上がりの抑制効果}

沈降物調査は, 上記の3区画と対照区の 2 箇所で も実施した . 夏季の沈降フラックスは, ST. 6 で $220 \mathrm{~g} / \mathrm{m}^{2} / \mathrm{d}$, ST. 4 で $100 \mathrm{~g} / \mathrm{m}^{2} / \mathrm{d}$, 冬季は ST. 4 で 270g/m²/d (ST. 6 は欠測) であった . 冬季で対照区 と試験区を比較すると，5cm 区画では同程度，他 2 区画では $1 / 3$ 程度である。このことより，10cm お よび $20 \mathrm{~cm}$ 区画では明らかに浮泥が再度舞い上がる 現象を抑制しており，5cm 区画では光の機能が低下 し, 舞い上がり抑制の観点からもほぼ原地盤と同程 度の状態に戻ったものと判断される．

\section{5 .まとめ}

海田湾において, 石炭灰造粒物の海底被覆による 海域環境改善効果の実証実験を開始し，概ね半年が 経過した段階での成果を取りまとめた．今後，継続 したモニタリング調査を行う計画となっており，さ らに詳細な機構解明に向けた研究を行う予定である。 本研究は光の途中段階ではあるが，環境改善に資す る方策として有用性が確かめられ，判明した現象を 中心に報告した . 得られた主な結論を以下に取りま とめた .

1) 改善効果の目標として, 被覆層における浮泥の 封じ込み, 水底質の改善, および生物生息環境の向 上の 3 点について，いずれも効果か認められた .
2) 被覆層間隙体積に占める浮泥体積の割合か指標と なり得ることが判り，5cm 区画では $40 \%$ に達し， ORP , T-S の底質項目についても対照区との相違が なくなりつつある.今後の推移を確認し，耐用性の 検討に有用な資料となると考えられる .

3) $10 \mathrm{~cm}$ おび $20 \mathrm{~cm}$ 区画では, 半年経過した段階で は概ね初期の状態を保ち，ORP，T- S , I L , PON の底 質項目から環境改善効果が発揮できていると考えら れる.ただし，水質や生物は底質の影響が間接的に 寄与する項目であると考え，継続的に推移を確認す る必要がある .

4) 今後の課題としては, 環境改善の効果を発現する メカニズムを解明し，より効率的な方法を整理する 必要がある。また, 被覆範囲と水質, 生物への改善 効果との関係を明らかにして, 広範な゙海域への適用 性について検討できる調査を継続する必要がある．

\section{参考文献}

1) 第 6 次水質総量規制の在り方について (答申) : 平 成 17 年 5 月, 中央環境番議会.

2) 広島湾再生行動計画: 平成 19 年 3 月，広島湾再生推 進会議.

3) 西田芳浩, 川内清光, 山本裕規, 首藤啓, 日比野忠 史 : 広島湾における効果的な底質改善技術の効果の 検証，海洋開発論文集，Vol. 25，pp. 407- 412， 2009.

4) 井上省吾, 日高和幸, 木村道夫, 日比野忠史, 首藤啓 : 石炭灰造粒物の海底散布時の沈降 - めり込み特性, 海洋 開発論文集, Vol.26, pp. 129-134, 2010.

5) 日比野忠史, 三戶勇吾, 今川昌孝, 駒井克昭, 木村道 夫 : へドロ被覆設計のための海底有機泥挙動の把握, 海 洋開発論文集, Vol.26, pp. 141-146， 2010.

6) 気象庁 $P$, 広島地方気象台の過去の気象データ

7) 環境保全調査, [オンライン] http://www1.kaiho.mlit. go.jp/KAN6/2_kaisho/suishitu/hiroshimawan.htm, 平成 22 年 2 月, 第六管区海上保安本部

8) 浅岡聡, 山本民次, 早川慎二郎: 石炭灰造粒物によ る硫化物イオンの除去, 海洋開発論文集 Vol.32, pp. 363 368, 2009. 